\title{
Kazakh Translations of M. Lermontov: "Alien" Text and Word-for-Word Translation
}

\author{
Kuralay B. Urazayeva* \\ Eurasian National University \\ 2 Satpayev Str., Astana, 010008, Kazakhstan
}

Received 13.01.2016, received in revised form 27.02.2016, accepted 04.04.2016

\begin{abstract}
In Kazakh translations of M.Yu. Lermontov's works in the 80-90-s, the combination of precise and free translations is observed with prevailing exact ones. From the 20-30-s up to present days, the same works of the Russian classicist are the objects of word-for-word translation.

The aim of this article is an intention to understand the reasons of prevailing word-for-word translations and to generalize wide-spread methods of its transfer. Non-randomness of prevailing word-for-word translation in the reviewed sphere is justified by the structure of the Kazakh language, correlation of the direct and indirect expressions in the translated text, relations of the significant with the signified. Such an approach allowed justifying the conception on word-for-word translation as an analytical one.

Other repeated, stable methods of meanings transfer also attract attention in word-for-word translation. It is a subjective and depictive descriptiveness and such relations between the expression and the graphics as the system of label relations, traditional symbolic character of the Kazakh poetic language that stipulate the rhetorical textual figures.

The results of the project can be applied in theory and practice of literary translation, history of literature.
\end{abstract}

Keywords: "alien text", Mikhail Lermontov, word-for-word translation, analytical translation, synthetic translation, Ilyas Dzhansugurov, Magzhan Zhumabayev, Kassym Amanzholov.

DOI: 10.17516/1997-1370-2016-9-5-1210-1220.

Research area: philology.

\section{Introduction}

Analyzing Kazakh translations of Mikhail Yu. Lermontov's works included into the anniversary (Lermontov, 1977a) and last editions (Lermontov, 1977б), we can outline the following tendencies. On the one hand, such practice by the first translator Abai Kunanbaev in 1980-90s was characterized by the strategies of accuracy-dominated and liberal translation
(Urazayeva, 2014，549-551). The prevalence of the accuracy in translation and existence of the so-called interpretative translations among them have opened the door to the clarification of the problem whether a number of works being considered as translations of Lermontov's poems are created by the Kazakh poet, and vice versa: whether that amount of literal works being publicized as works by Abai are actually written

(C) Siberian Federal University. All rights reserved

* Corresponding author E-mail address: kuralay_uraz@mail.ru 
by Lermontov (Urazayeva, 2015a, 170-180). This approach has become the ground for an objection toward the point of view by Z. Ahmetov and Kh.Sadykov expressed in "Lermontovskaya Enciclodepya" (eng. "Lermontov Encyclopedia") in 1981 concerning the dominance of literality in translations made by Abai (Ahmetov, Sadykov, 1981). On the other hand, one and the same art works by the Russian classic author became an object of literal translation in the 1920-30s. Finally, the comparison of Kazakh translations of Lermontov's poems performed from those years and up to the present time basically reflects the existence of a sole translation strategy -literality, in essence.

This article imposes the intention to identify factors of literality dominance in translations of M. Lermontov's works and describe the most significant ways of meanings preservation in these literal translations.

\section{Conceptological framework}

The comparison of accurate, liberal and literal Kazakh translations of Lermontov's poems (one and the same, as a rule) introduces some factors providing explication of the idea by M. Gasparov about a natural dominance of literal translation at the stage of initial acquaintance with a foreign culture (Gasparov, 1988, 57). Still, one should remember Gasparov focuses on the idea that different epochs and different readers require different translations, and more educated and sophisticated age needs literal translations since it wants to learn, to understand an "alien" culture and it does not fear to put itself to some bother. Secondly, there is an evident definiteness in the dominance of literal translation into the Kazakh language.

Moreover, there is another problem on detailing V. Rudnev's statement about the prevalence of synthetic translation in comparison with analytical one, and attribution of national translations made in the territory of the USSR to the synthetic ones.

The contrast between the analytical and synthetic translations Rudnev substantiates explains and uses it introduces in the translation of "Winnie-the-Pooh" by A.A. Milne and also in his works "Winni Pooh i philosophiya obydennogo yazyka (eng. "Winnie-the-Pooh and philosophy of everyday language") (Rudnev, 2000), "Morphologiya realnosti: Issledovaniye po "philosophii texta" (eng. "Morphology of reality: Survey of text in a philosophic way") (Rudnev, 1996), and "Proch ot realnosti: Issledovaniya po "philosophii texta" (eng "Away from reality: Survey of text in a philosophic way") (Rudnev, 1999). The author formulates the task for the analytical translation in the following way: “... not to give the reader an opportunity to forget even for a moment, that they read the text translated from the other language in merely a different way than their mother tongue, creating building the reality; to remind him about it within every word so that he should have no idea to be absorbed thoughtlessly in "what is happening", since in fact nothing is happening, but carefully follow instead those language parts played by the author and thus, consequently, the translator" (Rudnev, 2011, 21). The background for such vision that reflects the perception of essence and messages of literary texts V. Rudnev finds in the conception of the esthetic language function developed in the works by Ya. Mukarzhovskii, R. Jacobson and in his own researches too. Following Rudnev'svision, thesynthetictranslation should be aimed at "persuading the reader to forget not only about that he reads a translation from the foreign language, but also that this is the text which is written in any language" (Rudnev, 2011, 21).

The core of analytic translation is determined by the correspondence between the plane of expression and plane of content. Such Rudnev's 
understanding of the essence of analytic and synthetic translations grounds the point about the dominance of the last one in the Soviet translation tradition similarly to the popularity of Stanislavky's theatre in comparison with Brecht's theatre.

Rudnev's opinion about the fact that analytic languages, as contrasted with the synthetic ones, express basic grammatical meanings not through cases and conjugations, but prepositions and modal words - much like the rules of grammatical categories control in the Kazakh agglutinative language where lexical stems remain unchanged. The structure of the language may be a reason for the definiteness of literal translations by Kazakh poets interested in Lermontov's works as well.

Details mentioned above present us with the necessity to identify criteria for how to differentiate accurate and literal translations. We've made an assumption to compare accurate translations of Lermontov made by Abai and literal translations of the same works performed by other Kazakh translators (Urazayeva, 20156). This stage of the research is aimed at studying the system of correlation between "svoy - chuzhoy" (eng. "us/them") in literal translations as the way to reconstruct the idea of "Alien"; to recognize "sebya - svoego" (eng. "I-self/Mine") in "Alien"; to establish the equivalence of the "Alien". Having carried out the analysis of different types of correlations of direct and figurative meanings of Kazakh words, we are able to observe their connection with the relation between significatum and denotatum. The fact that literary translation is categorized as a cultural transfer phenomenon, influence, imitation, typological parallels and many other things brings the light upon the nature of word-for-word translation.

Suggested in this article the explanation of literal translation as an analytic one, has led to the determination of criteria grounding the difference between accurate and literal translation on the basis of correlation "us/them". Firstly, a deliberate permanence of the word-for-word translation is explained by literary facts and the meaning of typological analogies. Secondly, the correlation "us/them" revealed different forms displaying the national identification; different types of relations between the presentation of romantic characters in source texts and their interpretation formed within Kazakh translations what is caused by the resources of the Kazakh language in the sphere of semantic poetics and literary style features of Kazakh poets. Thirdly, the rhythm and metric systems within literal translation were marked with the overweight of quatrains in strophic and rhyming manners as $(a a b a+v v g v+g g d e+e e g e)$.

\section{Articulation of the problem}

Taking up the practice of answering the question why those Kazakh poets, who have translated Lermontov's works, are so engaged with the strategy of literal translation, we are allowed to demonstrate a new understanding of the word-for-word translation as an analytic one seen over the establishment of the types of literary relations in between Kazakh translations of works by the Russian poet.

The study is carried out with the means of immanent, formal and contrast-comparative methods.

\section{Discussion of the study matter}

The poem "Kinzhal" (eng. "Dagger") by M. Lermontov (1838) (II, 108) ${ }^{1}$ is famous due to literal translations by I. Zhansugurov (Zhansugurov, 1958, 593) and K. Amanzholov (Amanzholov, 2001, 58). Within a highly detailed similarity of these translations to the source text, we are to note a number of differences between these translations. Lermontov describes the stylistic power of the dagger as a symbol of friendship through 
the interpreting it in the context of metonymic nature. In this sense, it contains the core idea for the further "partner" - theme development where thematically and narratively associated "traveler" with its archetypical nature faces with the semantic contrast. The dagger, a "partner" for the persona, represents a didactically focused example of fidelity for some abstract "traveler". These two imageries reconstruct the plotline of friendship (the persona and the dagger) and love (lily hands, memories, leaving, suffering and melancholy) united by the motive of fidelity and permanence and marked with specifics and object psychologization ("tovarisch svetliy i kholodniy, sleza...stradaniya, tainstrvennoi pechali"). Moreover, the metonymic entity of dagger is it is a fellow traveler for the persona and "zalog lubvi nemoi" (eng. "a ticket for a dumb love") what makes him a "useful example". In this context the presence of "traveler" motive as a symbol of vagrancy, spirit wandering in particular, and search is determined by the emotional guideline of the truth found by the persona: the value lies in permanence of friendship and love, hard bitten in the flame of fights. "Gruzin" (eng. "Georgian") and "cherkes" (eng. "Circassian") are conventional and concrete in the same time as personification of the restless East and signs of the war theme.

The correlation between straight and figurative meanings becomes the basis for Kazakh literal translations of "Kinzhal". The ways of metaphoric picture creation in the Kazakh poetic mind used both by Zhansugurov and Amanzholov represent a semantic parallelism. Thus, the dagger being a "tovarisch" (eng. - "friend) is depicted by Zhansugurov as жолдасым өзіме аужал, i.e. it is not just a friend since the emotional emphasis stresses on the word аужал (eng. "reliance") (the translator uses a figurative meaning), while in Amanzholov's translation one finds серігім (eng. - "my fellow traveler") meaning the creation of imagery through literal translation. "Zadumchivy gruzin" (eng. "thoughtful Georgian") in Zhansugurov'v variant is cak (eng. - "vigilant, careful"), what is almost similar to the idea of jumping into detachment from the world. Amanzholov's translation preserves the straight meaning "thoughtful" ойшыл - serving as a compositional basis for the parallelism. "Cherkes svobodniy" (eng. "free Circassian") is over thought by Zhansugurov within its straight meaning - еркін (eng. "free, liberal") while in Amanzholov's translation he is written as қ̧аһарлы (eng. "rugged"), expressing the figurative meaning of "grozny boi" (eng. "severe fight") from the source text. "Grozniy boi" Zhansugurov translates using emotional modality - тілеп жанжал (eng. "keen on fighting"). There comes a neutralization of the revenge-motive which constructs the theme of retribution as the ground for the spirit mutuality and metonymy of a "fighter", "warrior" and his dagger as friends.

Zhansugurov neutralizes Georgian's revenge, while Amanzholov preserves it. Moreover, Amanzholov avoid repetitions as the Circassian in his variant is "rugged".

The question of how to translate the word combination "lileinaya ruka" (eng. "lily hand") appears to be a real obstacle. Lileinaya (lily) means "by its whiteness, softness resembling a lily". For example, "lileinie plechi" (eng. "lily shoulders") in A. Pushkin's "Ruslan and Ludmila". Lacking a common ethnic material, the Russian and Kazakh languages create a space for the stylistic maneuver: Zhansugurov translates it as балауса құол meaning "the hand of a young girl" (balausa in its straight meaning is understood as a sprout); Amanzholov suggests a metonymy сал білек (eng. "elegant wrist"), i.e. a sleeve covering the wrist (Tolkovy slowar kazakhskogo yazyka, 1999, 548) ${ }^{2}$. 
Both variants contain quite an interesting translation of suffering. Aside from preserving the image of "zhemchuzhina stradaniy" (eng. "a jewel of suffering") by both translators, Zhansugurov transforms the sound imitation dipdip into parallelism to trembling of steal over the "quivering flame"; the line "ostanovivschiisya vzglyad" (eng. "fixed eyes") is translated by Amanzholov as the staring eyes full of tears, and as қъадалванда (eng. “ steady”) by Zhansugurov.

Lermontov's "trepetniy ogon" (eng. "quivering flame") can be characterized as an extended metaphor in both translations. Thus, Zhansugurov in his translation suggests a metaphor of inner flame that has become a compositional basis for the motive of suffering: "svetlaya sleza - zhemchuzhina stradaniya" «Іикі өртім ұшқыны еді маржан» (eng. "а spark of suffering inside of me was a jewel"). There is also an axiological element - қ̧acuemmi жас (eng. "holly tear"). «Асыл от» (eng. "precious (pure) flame") and «нұр сәулесі» (eng. "sunbeams" used when one speaks about the eyes of beloved woman) suggested in translations by Amanzholov evoke poetic formulaicity of the Kazakhs .

A rhetoric figure in the final part of the original text creates a recitative intonation through an oath ("ne izmenius i budu tverd dushoi") and repetition ("kak ty, kak ty"). While Amanzholov translates the oath as айнымас жаным менің (eng. "my soul won't change") and preserves the repetition өзіңдей, дәл өзіңдей (eng. "as you, as you"), Zhansugurov Despite his strategy of literal keeping of the oath Zhangurusov, uses a rhetoric question in translation of the repetition: Сен құандайсың?? Қандайсың, достым темір? (eng. 'Where are you? Where are you, my steal friend?')

The metric and rhythmic structures of these Kazakh translations are absolutely the same: in strophic both Amanzholov and Zhansugurov follow the quatrains as well as Abai and many other Kazakh translators of Lermontov's works, whereas the original text has only two strophes. Besides Amanzholov and Zhansugurov have a

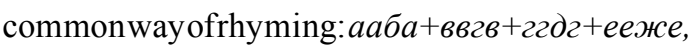
instead of абаб + вгвгдедежзжз in the source poem.

The other example of literal translation of Lermontov's poem "Evreiskaya melodiya. Dusha moya mrachna. Skorey, pevets, skorey" (eng. "Hebrew Melody”) (1836) (II, 77) is “Еврей сазы” by K. Amanzholov (Amanzholov, 2001, 54). A romantic soul disease ("dusha moia mrachna"/ eng. "my soul is ill") is straightly transformed by the Kazakh poet as жаралы жаным менің. Still, the "alien" text which uses such bookish images as "zolotaya arfa" eng. "golden harp"), "venets" (eng. "crown"), "kubok smerti polniy yada" (eng. "bowl of Death filled with poison") creates challenges in translation, motivating him towards a descriptive manner and contextual translation.

Being an ancient symbol of art the "Golden harp" is replaced by алтын қольы (eng. "golden hand") of the singer. The "crown", i.e. the crown of thorns torturing the head of poet, relates to the lyrical narration to the singer: "Pust budet pesn tvoya dika" (eng. "Let your song be wild"). The desire to get rid of suffering is decided by Lermontov in quite a traditional way of romantic detachment characterized by an esthetic neglecting. For the translator preservation of such expression is probable within the combination of two characters - the persona and explicit "singer". Amanzholov adds an idea of personal fortune as a trial: тавдырымдай (eng. "as my fortune"). "Mne tyagostni veselya zvuki!" (eng. "I don't want to hear sounds of joy") is translated by the Kazakh poet word-for-word: Маван жат шатmық (eng. "the joy is strange for me") and thus he prepares the ground for strengthening of emotional ties between the persona and explicit “singer”: қүрбым (eng. "my fellow”). 
The translation includes two comparisons with poison: "kubok smerti polniy yada" (eng. "bowl of Death filled with poison") is transformed into the metaphor of a "soul sodden with poison" / Сіңъіріп көп қ̧асірет жұтқ̧ан ұдай (eng. "I drank the suffering as drop by drop like poison"). The strategy of literal translation is based on the object description.

Lermontov's “Dary Tereka” (eng. "Terek’s Sacraments) (1839) (II, 128-130) is famous in the word-for-word translation by K. Amanzholov as “Теректің сыйлықтары” (Amanzholov, 2001, 59-61). In this case, literal translation appears due to object figural description. However, it has a new formula for the literal translation, i.e. the system of etiquette relations. The traditional formula of one generation mentioned above in the case of "Hebrew Melody", is repeated here. Thus, Darial to Terek in Amanzholov's variant is құрдас, or a "fellow”. Such sustainability of the rhetoric nature and repetition of formulas are one of the methods of literal translation.

K. Amanzholov quite literary translates the line "Trup kazachki molodoy" (eng. "corpse of a young Cossack woman") as the metaphor with mythological taboo element: Көз жұма тәтті ұйықттаван (eng. "deeply falling asleep with closed eyes"). The choice of literal translation initiates the formulaic language for the translator, which expresses the beauty and chastity of this young girl: талай жан жасын сывулы (eng. "made a lot of man crying").

The poem "Smert' Poeta" (eng. "Death of the Poet") (1837) (II, 84-86) is famous in translations by Zhansugurov "Ақыын өлімі" (1937) (Zhansugurov, 1958, 590-591) and Amanzholov «Ақыьн ажальl» (Amanzholov, $1958,54-55)$. We are to note the similarity of translations with the source text, so the similarity between them. Besides, gradation in imageries reflects new methods in the strategy of literal translation.
Firstly, there are some shades of synonymic symbols of death - өлім (in Zhansugurov's work) and ажал (in Amanzholov's work). In order to understand such gradation of meanings, one should identify different forms of communication inside the whole strategy of literal translation. Thus, "Sudby svershitsya prigovor" (eng. "Let the verdict of the fate come true!") is literally translated by Amanzholov and has the nature of an accusatory invective. In Zhansugurov's translation the idea of a "cruel treat" emphasizes the ethical aspect containing not only the concept "man's honor": Еpдiң, басын ермек етіп жыртаққа (eng. "one entertains with the man's head for mockers") but also expressed through the musical imagery. The assonance intoned by the phoneme [e] fixes "cut" borders of the words.

The stating word "ubiytsa" (eng. "murder") in these two translations by the Kazakh poets is expressed by synonyms "evildoer, executioner", besides in Zhansugurov's work he is also characterized as "dishonest and soulless". The sarcastic "I chto za divo" (eng. "What a miracle") is clothed by Zhansugurov with the invective of "disgrace". The fateful rhythm in "Pustoye serdtse biotsya rovno" (eng. "The empty heart beats smoothly") is translated by Zhansugurov as "Serdtse biotsya tikho" (eng. "The heart beats soundlessly") and by Amanzholov as "Razve drognet szhavsheesya serdtse?" (eng. "Whether the sunken heart would beat again?"), i.e. literally, қуыс жүрек means "sunken or cramped heart". In the context of Sufism the notion of "cramped" is an attribute of the other world. Zhansugurov perceives the death of the Poet within the tragedy of leaving this world and presents it in the following formula: "Why has he come to the other cramped world?". While Zhansugurov introduces the image of grave folding the persona, Amanzholov thinks about a "haven" mentioned in the source text as about a 
"small cage". This is a reason for the relevance of revenge in Zhansugurov's translation considered as a sentence of the "Hell" instead of the divine scourge.

In Zhansugurov's translation the opposition of "white" and "black" is set against the symbol of "chernaya krov" (eng. "dark blood") in the original text: "Even if you spill all your dark blood (on the Poet)/ White blood of the Poet nobody would wipe out". Amanzholov translates the whole insolvability of the conflict through the opposition between "dark blood of evils" and the "holly blood of the Poet". Thus, the message of severe negation in Lermontov's poem, his angry invective which is almost absolutely nontranslatable due to the unique texture of the lofty language created by archaic lexis, receive the accusatory intonation in the translation made by a narrative character of the plot and opposition in the sphere of the ethical conflict.

The semantic border between өлім and ажал lies in strengthening of the metaphysical implication (өлім means "the death as otherness") and sacral essence (ажал means "the death as a fate").

The poem "Uznik" (eng. "Prisoner") (1837) (II, 89-90) is most commonly associated with the translations by M. Zhumabayev (Zhumabayev, 1989, 354-355), K. Amanzholov (Amanzholov, 2001, 57) titled as "Тұтқын” and by I. Zhansugurov as "Тілек" (еng. "Desire") (Zhansugurov, 1958, 594). The differences in the romantic chronotope are interesting here. Zhumabayev suggests the word дарива (eng. "wide spaces") that gains a complete metaphoric meaning in the combination with such synonyms as шіркін and әттен that express "regret about impossibility of something". In Zhumabayev's variant "A young girl with black eyes is probably kissed by an alien, by a stranger". In this case an intensification of the "alien" within the poetic context is semantically equivalent to "enemy".
An implicit foe, a stranger is a way for the translator to achieve that dramatic insolvability in the conflict. Mastery skills of the Kazakh translator are explained by the development of a psychological scene which structures musical and color imageries in a specific way.

The Russian line "Tusklo svetit luch lampady/ Umirayuschim ognem" is translated as "Шамады әлсіз жарывын / Сөнетін оттай сорль шам" (eng. "dissipate the dismal light/As dyeing out flame a poor lamp"). A dismal light and comparison with a "dying out flame" of the lamp are expressed by alliteration in the translation.

The background and rhythmical picture of the last quatrain in the source text which imitates steps of a watch, is created through the smooth change of the interlaced rhyme into a plain one in the last quatrain (in other strophes the interlaced rhyme is combined with a plain one): "Tolko slyshno: za dveriami//, Zvuchnomernimi shagami,/ Khodit v tishine nochnoi/ Bezotvetniy chasovoy".

In all the strophes Zhumabayev suggests the interlaced rhyme. The feature of the last strophe (since the others are characterized by an alteration of 7-syllabic and 8-syllabic lines) which is also focused on the sound imitation of the step rhythm, causes a change in the syllabic form of the poem: “Естіледі жалғыз-ақ (eng. - "just is heard”) - 7 syllables; Ар-жағында есіктің (eng. - "outside the door") - 7 syllables; Күзетші жүр үнсіз сақ (eng. "as a watch walks silently") - 7 syllables; Аяғын басқан есеппен (eng. "measuring the steps") - 8 syllables.

In Zhansugurov's variant of translation only first four lines are accurately reconstructed: further there is an atypical for the Kazakh translation practice strategy of liberal translation with emphasizing of Lermontov's images and motives of "sea", "sail", "fountain", "desire for freedom", which is subjected to the intention to interpret the theme of "freedom" and liberty in 
symbols developed within the context of Byronian romanticism. Presumably, the explanation lies in the date of the translation, since 1937 was the last year of the Kazakh poet's life in prison.

The literal translation by Amanzholov operates common categories for a steppe-dweller. A beautiful girl is Қара көзді құарындас. In this case, an etiquette form of addressing to a young girl (eng. "small sister") initiates the replacement of a folklore motive of a "gorgeous terem" by the material topic үлде киген, гүл сүйіn, where үлде means "an expensive delicate textile". Symbolization of luxury and wellness taken in within the context of beliefs peculiar to the steppe-dweller leads to the mechanism of literal translation.

The total negation of the original text "Steny goliye krugom" (eng. "Naked walls around there") is expressed by the Kazakh poet through the sound effect of denial that appears to be quite alive to sibilants: “Жан-жағым жар, сыз бен шаң" (eng. "dust and dampness"). In order to repeat rhythmic steps of the watch possessing the semantic role in the source text, Amanzholov finds a different phonetic approach. "Zvuchnomernimi shagami" (eng. "Sound-measured steps") is translated as ерсіл-құрсыл басады нық (eng. "to step steadily back and forth"). The decision found by the translation is comparable with the experience of Vadim Rudnev: Alongside with the importance of formal metric plane, the authors "preserve metrics due to greater liberality in lexico-semantic plane. In those cases where, as it might be seemed, the semantics is more important, we change the metrics. We translated lines in "Winnie-the Pooh" by the Russian metres with the Russian metric-semantic allusions".

The other justification in favor to the understanding of word-for-word translation as an analytic one is the creation of meditative lyrics though color and sound imageries. The Russian poem by M. Lermontov "Kogda volnuetsia zhelteiuschaia niva" (1837) (II, 92) is famous for the Kazakh reader in translation by M. Zhumabayev - “Сарғайып келген егін толқындаса" (Zhumabayev, 1989, 363). The two-part composition of the source text is created by the contrast of two scenes: the colour imagery suggested by the straight meaning of epithets "zhelteiuschaya niva" (eng. "flavescent fields"), "malinovaya sliva” (eng. "raspberry-red plum"), "zelenogo listka" (eng. "green leaves"), "studioniy kluch" (eng. "cold spring") and metaphoric epithets "runmianiy vecher" (eng. "rosy evening"), "utra chas zlatoy" (eng. "gold hours in the morning"), "landysh serebristiy" (eng. "silver lily-of-the-valley"). This is a confession with an implicit "talker".

Zhumabayev almost literally reproduces the color imagery of the source text, with the exception of "мойыл қаймақ”" (eng. "the whiteness of bird cherry is compared with a sour cream") replacing the "raspberry-red plum". The "rosy evening" is translated as қырмызы кеш. Names of textiles, which are considered as the basis for the Kazakh women onomastics, posses the specific image structure. Қырмызы means "red silk" fixing the idea of something expensive, luxurious and gorgeous. The "rosy evening" is characterized by a physiological features implied in the realistic tendency in the scenery creation. The materialistic side of the translation uses the vision of attributes of a practical beauty.

The romantic motive of a "misty dream" in the source text is replaced by "misty thoughts". Suggestiveness of the original text ("misty", "mysterious") is changed with sacral semiotics of the white color, of mystic Moon-color. The humility of the soul-worries in the source text is set against the "calm of rebellious spirit".

The line "I, pogruzhaya mysl' v kakoito smutlii son/ Lepechet mne tainstvennuyu sagu" forms the motive of the nature harmony transformation into a harmony of the higher 
level. The translation presents the manner of a straight meaning expression әңзіме zыı followed by preservation of the narrative idea. "Togda smiriaetsya dushi moyey trevoga" is translated as "сол уақыт жай табады асау жаным" (eng. "my soul then recovers poise"); "Togda raskhodyatsya morschini na chele" as «сол уақыыт жадырайды қ̧ас-қ̧абавым» (eng. "then my brow smoothes").

The complexity in reproduction of the original romantic stream in translations is determined by distinctive Christian axiology and by the change from the realistic picture of the Russian landscape to philosophic and anthropological essence. The second part accepts the nature of a lofty confession with axiological tones. In this sense, the idea of Christian and Orthodox humbling, obtaining the truth ("happiness"), "heaven" and "earth" combination within the personal life, the harmony between "I-concept" and "Divineconcept" are the ways to create another world or "peaceful space".

The final part of the plot in the source text "I schastiye ya mogu postignut' na zemle,/ I v nebesakh ya vizhu boga" obtains the character of a confession, uncovering the God in one's soul. In translation: "Шын бақты тапқ̧андай боп осы жерде-ақ," (eng. "the true happiness seem to be obtained here, on this earth by me") / Көремін

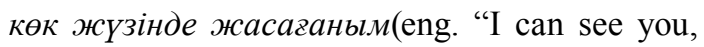
my God, in the face of Heaven"): a typical for the contemplative psychology of a nomad motive of projection preserves the meaning of appearance. The suggestiveness, instability of happiness is highlighted by the symmetry between the cosmic vertical and semiotics of reflection. Thus, the romantic line of the source text has been reconstructed within the strategy of literal translation with preservation of crucial components.

The stability of word-for-word translation is accompanied by an interesting repetition in different variants made since Abai's works. We speak about the tradition in translation of Lermontov's works in strophic sense with quatrains (with few exceptions). All the rhyming methods often have the form ааба. For example, in four quatrains they

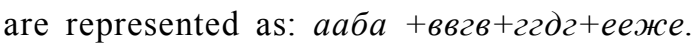
Such specific feature of the metric structure which relates to Abai's findings in the sphere of Kazakh verses; which has not only become the peculiarity of the Kazakh system of versification but also included into the structure of metric organization of literally translated texts, has also played the dominant role in this strategy of translation.

\section{Conclusion}

The relevance of the assumption described above lies in the explanation of non-randomness of the literal translation within the considered area due to the structure of the Kazakh language, correlation of figurative and straight expressions in translated texts, relations between denotatum and significatum and development of a new attitude toward the literal translation considered as being of analytic nature.

Other repeated steady ways for meanings communication in lateral translation should also be noted. They are: object figural description and such relations between expression and description as the system of etiquette regulations and traditional formulaicity of the Kazakh poetic language that reasons rhetoric formulas in texts. 


\section{References}

Amanzholov K.(2001). Sobraniye sochinenii v 2 tomah. Vtoroi tom. Perevody, dramaticheskiye proizvedeniya. [Collection of writings in 2 volumes. Translations, dramatic pieces of work]. Almaty: TOO "Tengry".

Ahmetov Zh.A., Sadykov Kh. N. (1981). Kazakhskaya literatura [Kazakh literature]. Lermontovskaya entsiklopediya. [Lermontov's encyclopedia]. Moscow: Sovetskaya entsiklopediya. Available at: http://feb-web.ru/feb/lermenc/lre/lre-003-.htm (December 18, 2013)

Gasparov M.L. (1988). Bryusov i bukvalizm [Bryusov and literalism], In Poetica perevoda [Poetics of translation]. Moscow: Raduga, $29-61$.

Lermontov M.Yu. (1954-1957). Sochineniya v 6 tomah [Writings in 6 volumes]. MoscowLeningrad: Izdatelstvo AN SSSR,

Lermontov M.Yu. (1977a). Stihotvoreniya, malenkiye poemy. Pervyi tom. [Songs, small poems. Volume 1], In Izbrannoye. V dvuh tomah. [Selecta. In two volumes] Almaty: Zhazushy.

Lermontov M.Yu. (1977б). Poemy.Vtoroi tom. [Songs. Volume 2], In Izbrannoye. V dvuh tomah. [Selecta. In two volumes] Almaty: Zhazushy.

Lermontov M.Yu. (2004). Stihotvoreniya. Poemy. Geroi nashego vremeni [Songs. Poems. Hero of our time]. Astana: Audarma.

Rudnev V. (2011). Winni Pooh i philosophiya obydennogo yazyka [Winnie-the-Pooh and philosophy of everyday language]. Moscow: Ast-Astrel.

Rudnev V. (1996). Morphologiya realnosti: Issledovaniye po "philosophii texta" [Morphology of reality: Survey of text in a philosophic way]. Moscow: Russkoye phenomenologicheskoye obshestvo.

Rudnev V. (1999). Proch ot realnosti: Issledovaniya po "philosophii texta" [Away from reality: Survey of text in a philosophic way]. Moscow: Agraf.

(1999). Tolkovyi slowar kazakhskogo yazyka [Explanatory dictionary of the Kazakh language]. Almaty: Daik-Press.

Urazayeva K.B. (2014). Abai Kunanbayev. Lermontov. Entsiklopedicheskii spravochnik. [Lermontov. Encyclopedic reference book]. Moscow: Indrik, 549 - 551.

Urazayeva K.B (2015a). Abai Kunanbayev $\square$ perevodchik Lermontova [Abai Kunanbayev Lermontov's translator], In Prostor [Spaces], 2, 170 -180.

Urazayeva K.B. (2015). Mnozhestvennost smyslov svoego / chozhogo v strategii bukvalnogo perevoda (kazakhskiye perevody liriki M. Lermontova) [Multiplicity of meanings of own / somebody else's in the strategy of word-for-word translation (Kazakh translations of M. Lermontov's lyrics)], In Philogo-kommunikativnye issledovaniya-2015 [Studies in Philology and Communication-2015]. Barnaul: izdatelstvo Altaiskogo gosudarstvennogo universiteta.

Ushakov D.N. Bolshoi tolkovyi slowar sovremennogo russkogo yazyka [Large definition dictionary of modern Russian language], available at: atthe.ucoz.ru/news/d_n_ushakov_bolshoj_ tolkovyj_slovar_sovremennogo_russkogo_jazyka_online_versija_russkij_jazyk/2012-08-01-21 (October 22, 2015).

Zhansugurov Il. (1958). Sochineniya [Writings]. Stihotvoreniya i poemy. [Songs and poems]. Almaty: izdaniya Goslitizdata.

Zhumabayev M. (1989). Proizvedeniya: stihotvoreniya, poemy, proza [Writings: songs, poems, prose]. Almaty: Zhazyshy. 


\section{Казахские переводы М. Лермонтова: «Чужой» текст и буквальный перевод}

К.Б. Уразаева

Евразийский начиональный университет Казахстан, 010008, Астана, ул. Сатпаева, 2

В казахских переводах произведений М.Ю. Лермонтова 80-90-х годов наблюдается соединение вольных и буквальных стратегий перевода, с явным преобладанием последних. Начиная с 20-30 годов и до настоящего момента одни и те же работы русского классика становились объектами для буквального перевода.

Целью данной статьи является стремление понять причины доминирования буквального перевода, а также обзор основных методов его осуществления. Неслучайность доминирования буквального перевода в рамках анализируемой сферы обусловлена структурой казахского языка, корреляиией прямого и переносного способов выражения в переводном тесте, отнотениями между означаемым и означаютим. Данный подход позволил обосновать кониепџию рассмотрения буквального перевода в качестве аналитического.

Другие повторяющиеся устоявшиеся методы передачи значения при буквальном переводе также заслуживают внимания. Среди них выделяются объективная и субъективная описательность, а также такие связи между выражением и описанием, как система этикетных отношений, традииионный характер символов в казахской поэзии с наложением риторических фигур.

Результаты данного исследования могут быть применены в курсах по теории и практике буквального перевода, а также истории литературы.

Ключевые слова: «чужой» текст, Михаил Лермонтов, буквальный перевод, аналитический перевод, синтетический перевод, Ильяс Джансугуров, Маджан Жумамбаев, Кассым Аманжолов.

Научная спечиальность: 10.00.00 - филологические науки. 